\title{
Social Media: A New Perspective of TEFL
}

\author{
Hager Gamal Ahmed Labib al-Tonsi \\ Lecturer of English Curriculum \& Instruction (TEFL) \\ Faculty of Education, Arish University
}

\begin{abstract}
Social media has become an integral part of students' lives. The number of students' social media accounts in Egypt is increasing rapidly. Social media open new horizons for learning. Students can share, comment, and follow any topic of their interests. Availability of videos, audios, and photos encourages students to participate in this virtual community. Teachers of English should benefit from the ubiquitous learning offered by social media to develop their students' language skills anywhere and anytime. They should offer variety of activities using different social media applications in light of their students' interests so that learning English will become a continuous process crossing the walls of classrooms. This article highlights both the possibilities and benefits of using social media in TEFL in an attempt to encourage teachers to implement these applications in their teaching.
\end{abstract}

Key words: social media, ubiquitous learning, and TEFL

\section{Introduction}

The rapid change in the context of education paves the way for innovative uses of technology to satisfy students' needs and expectations (Gros, Kinshuk, \& Maina, 2016). Veletsianos (2010) identifies educational technology as tools, concepts, and innovations used in education, hence it requires different approaches to teaching, learning, and assessment. Feldmann (2014) asserts that technology has changed the way of learning and teaching in the last twenty years.

Richardson (2010) defines learning as the ability to construct and participate in global networks. It is a continuous conversation among students and teachers. Bonsignore, Hansen, Galyardt, Aleahmad, and Hargadon (2011) add that students should share learning responsibilities and teachers should master the skills of online learning. Teachers who use social media to develop their professional and technical knowledge can guide their learners to use them effectively and ethically.

Mozaheb, Seifoori, and Beigi (2013) tried to shed light on the teaching practices of two effective EFL writing lecturers at an Iranian university. Data were collected via classroom observations, journal writings, and 
interviews. Researchers observed and videotaped 14 sessions. Data analysis revealed that the participants integrated different technological tools while teaching the processes of writing, thus increasing students' engagement and motivation.

Oberg and Daniels (2013) highlighted the effect of using a self-paced instructional method based on the use of Apple's iPod devices on developing English language skills. Participants were 120 first year Japanese university students. They were divided into an experimental group $(n=60)$ and a control one $(n=60)$. Statistical analysis of students' scores on a standardized English language test after finishing the course revealed that the experimental group had higher scores than the control one due to the use of the self- paced method based on Apple's iPod devices. According to the statistical analysis of a survey administered to the control group to examine their attitudes towards the method, they had positive attitudes.

Bani abdelrahman (2013) explored the effect of using online games and digital storytelling on ninth grade students' vocabulary of English language. The study was carried out during the first semester of the academic year 2013 at a public school in Jordan. Participants were 140 students divided into experimental group $(n=70)$ and a control one $(n=70)$. Analysis of the results of the vocabulary test revealed that students in the experimental group achieved better scores than their peers in the control one.

The research of Hwang, Chen, Huang, and Chen (2014) examined the effect of a proposed situational learning system on developing elementary school students writing skills of EFL. A class of 28 students was identified as the experimental group, and another class of 31 students was assigned as the control group at an elementary school in Taiwan. Experimental group students were assigned writing situational tasks using the support of mobile phones in familiar situations while the other group were assigned the same tasks without the use of mobile phones. Results indicated a significant difference in writing skills between the two groups in favor of the experimental one who wrote more sentences and described the target objects more clearly than the control group.

EL-Desouky (2015) investigated the effectiveness of using Mobile Assisted Language Learning to develop EFL listening skills and learner autonomy for secondary stage female students. Participants of the study 
were two classes of first year secondary stage at a public school in Damietta, an Egyptian governorate, and were divided into a control group and an experimental one. A program based on Mobile Assisted Language Learning was administered to the experimental group while the control one received regular teaching. Students' scores on the listening post- test revealed the effectiveness of the proposed program in developing students' listening skills. Also, the experimental group students outperformed their peers in the control group on the post administration of the autonomy scale.

Online learning has become a part of the educational environment, especially in higher education (Anderson,2008). Tailoring online learning opportunities to meet the needs of students who wish to learn anywhere and anytime is a challenge (Hutchison ,Tin, \& Cao,2008). Maintaining that each student can find the types of support and opportunities needed is also a challenge (Bonsignore et al., 2011).

Zaina, Ameida, and Torres (2014) claim that online learning lacks the resources that motivate students. Schroeder (2011) adds that the lack of nonverbal cues makes it difficult to communicate with learners. Zhang (2009) concludes that the physical absence of students and teachers in the online learning environment makes students experience neither the advantages nor the pressures associated with traditional classrooms.

The following suggestions address the previously mentioned challenges. Developing students' independence and providing instant support lead to the success of the online learning environment (Moisey \& Hughes, 2008). Further, Notification offers feedback to learners who tend to disengage when there is lack of non verbal cues (Anderson, 2008). The National Dropout Center suggests that online learning solves students' dropout and disengagement problems. It encourages learners to interact with different colleagues, teachers, and experts (Pletka, 2007).

Armfield, Armfield, and Blocher (2015), Green, Hechter, Tysinger, and Chassereau (2014), Mioduser (2015), Papa (2015), and Fox-Turnbull (2015) highlight that Web2.0 learning is based on Vygotsky's theory of social constructivism. Learning is not only a teacher transmitting knowledge but also a learner constructing new knowledge in light of previous schemas. Learners are often in a zone of proximal development where there is a gap between what learners can achieve individually and 
their potentials when receiving guidance. Web 2.0 learning transforms the learning situation into a social trial.

Web 2.0 changes teaching and learning through openness, interactivity, and sociability (Manca \& Ranieri, 2016). Web 2.0 offers online communities for people with common interests and activities. It develops creativity and collaboration through information sharing (Harris, 2008). Further, Web 2.0 tools provide authentic learning opportunities for students to practice English language skills. They allow students to use academic language in meaningful ways. Students work together in completing academic tasks and participate in active discussions with teachers (Crane, 2012). Constructing and sharing knowledge in collaborative activities enable students to retain such knowledge (Armfield et al., 2015).

Baöz (2016) investigated EFL teachers' attitudes towards language learning through social media. Participants were 120 pre-service EFL teachers: 30 participants from each grade level (freshman, sophomore, junior, and senior). They were enrolled in the English Language Teaching Department of a state university in Turkey in the academic year of 20142015. Results of the administered questionnaire revealed that the participants had positive attitudes towards the use of social media in language learning. They believed that using social media would enable them to develop different language skills.

Students often use social media daily outside classrooms and rarely inside them (Crane, 2012). Free Apps cause wide spread of social media. Conversely, the learning environment does not cope with such spread due to school networking policies and complexity of integrating social media effectively in the learning environment (Mao, 2014). Integrating social media enables students to share and discuss their ideas, search for information and resources, and consult their peers and teachers (SantosTrigo \& Reyes-Martínez, 2014).

Nisr (2014) explored English language teachers' views on the use of social media for professional development. Participants were 50 Libyan English language teachers of different ages and teaching experiences. Data analysis of participants' responses to a questionnaire revealed that they used social media for social and professional educational purposes as social media enabled them to acquire new skills and knowledge. 
According to a report issued by Center of Technological Innovation on December 22nd, 2015, Egypt has the highest number of Facebook users in the Arab World and 52\% of its users are under the age of 25. ("Vision of e-marketing in Egypt", 2015). Thus, millions of students in Egypt use social media daily for communication. They spend a lot of their time without guidance or support. Teachers of EFL should benefit from the facilities offered by social media and use them to satisfy students' learning needs, increase their motivation, enhance their learning autonomy, and develop their attitudes towards EFL.

As stated above, technology has changed the concept of learning. Learning is defined as a continuous discussion between students and their teachers whether inside or outside the classroom. Online learning offers teachers the opportunity to scaffold their students' learning to satisfy their needs. EFL teachers should benefit from students' eagerness to use social media and offer activities that engage them and develop their language skills.

\section{Aim}

This review article aims at achieving the following:

- Highlighting the possibilities of using social media in TEFL.

- Illustrating the pros and cons of using social media in EFL classrooms.

\section{Significance}

The significance of this review article could be summarized in the following:

1- Highlighting the effectiveness of using social media in developing different EFL skills.

2- Providing guidelines for integrating social media into TEFL.

\section{Review of Literature and Related Studies}

\section{Web 2.0}

Anderson (2008) differentiates between Web 2.0 and social software. Social software focuses on supporting the social relationships, while Web 2.0 refers to technical and network applications. Many social software tools can be described as Web 2.0 tools, but not all Web 2.0 tools focus on meeting social needs. To Harris (2008), Web 2.0 can be considered as a platform since it is used to create other technologies. It is a system where some applications can work. Web 2.0 and its applications create a 
new type of information sharing: The web becomes a community of users sharing and creating content that benefits everyone.

Caplan (2008) offers another view of Web2.0. To him, Web 2.0 is a different way to use the Web that depends on social networking, such as blogs, wikis, and podcasts. Bonsignore et al. ( 2011) add that Web2.0 refers to accessible social media that support collaboration in a community of practice. Using social media enables learners to engage in tailored learning content and experiences.

Web 2.0 brings people together to talk, make new friends, and share ideas, activities, and interests. They include social media such as blogs, Twitter, Facebook, Edmodo, My Space, YouTube, and many other applications. Teachers can benefit from Web 2.0 applications in publishing content, videos, and photos without having programming skills. Teachers can continue the classroom discussion, post assignments, and offer assistance to personalize learning activities via social media. Hence, such applications are used to support relationships with students and share learning content (Crane, 2012). Shieh (2012) asserts that teachers' beliefs affect their perceptions of learning and technology integration in classroom practices.

Web 2.0 interactive media are free, easy to access, and designed to support collaborative knowledge creation and sharing (Dede,2011).Web2.0 technologies allow students to write, edit, and produce learning content (Pletka, 2007). Web 2.0 is the writing web that allows users to create and share their materials using Internet mobile access (Fahy, 2008). Students are interested in social networks to contact peers and update their knowledge (Rosen, 2009).

To sum up, mobile devices should be integrated in the learning process. Mobile applications resemble musical instruments that need skillful composers. Such skillful composers are the teachers who analyze students' needs, learning situations, and pedagogy to motivate students to be responsible for their own learning (McClanahan \& Stojke, 2015).

Danciua and Grosseck (2011) offer some recommendations for teachers when using social media in reading sessions. The topics selected should be interesting, familiar, and useful for students. Teachers should start with familiar topics, then move from simple to complex, and concrete to abstract. Immediate feedback should be offered to maintain the efficiency of the learning process. 


\section{Hager Gamal Ahmed Labib al-Tonsi}

Web 2.0 is the current generation of the Web. It is a platform with many applications including social media. Web 2.0 applications enhance the social constructivism theory of learning. Students participate actively in the learning situation by interacting to posts, messages, tweets, photos, and videos. Students create, share, like, and comment on the learning content. Active participation encourages students to benefit from the ubiquitous learning supported by the integration of Web 2.0 applications, especially social media, in education. The following is a brief description of the most commonly social media applications used in education:

\section{Facebook}

According to a report issued by Daily news Egypt on April $1^{\text {st }}, 2016$, there is 28 million Facebook users in Egypt. Around 17\% of users are between 13 and 17 years old and 65\% are between 18 and 34 years old (" Internet and social media use", 2016). Armfield et al. (2015), Crane (2012), and Harris(2008) state that Facebook is a social network launched in February 2004. It can be used in Web2.0 learning since it offers many facilities. Facebook enables students and teachers to have their personal profiles, pages, and groups. The homepage of each user includes personal information, News Feed, Wall posts, Pokes, and Status Updates. Students can message each other and their teachers too, vote in polls, participate in discussions, upload videos and images, and share links for free. Crane (2012) and Riedl (2008) highlight one of the facilities offered by Facebook. Tag is a keyword-based classification assigned to a specific item to describe it. Students attach keywords or phrases- tags- to items to organize and share them.

Yusof, Manan, and Alias (2011) investigated the potential of using Facebook Notes to offer peer feedback to students' written work. The study was limited to the planning stage of the writing process. Participants were 20 students in an educational diploma at a university in Malysia. The study revealed that that the students, with guidance from the writing teacher, were able to provide constructive feedback to their peers. The comments and suggestions posted on the Facebook Notes were found to be useful in helping their peers improve their outlines and first drafts. Students' interviews revealed that they learnt to be more accurate while self-editing their writing.

El-Sawy (2015) investigated the effect of using Facebook as a free writing tool on improving students' writing skills. Participants were 82 English majors from Damanhour Faculty of Education. They were 
divided into a control group $(n=41)$ and an experimental one $(n=41)$. An essay writing test and another test for writing short comments were administered to the participants. The scoring of the tests depended on rubrics developed by the researcher. Statistical analysis of students' answers to the two tests revealed statistical differences in favor of the experimental group. It was concluded that Facebook was effective in developing university students' EFL writing skills.

\section{Blogs}

Armfield et al. (2015) and Harris (2008) highlight that Blogs appeared in the mid-1990s to produce daily information. A Blog is a website used as textual web diaries, then it becomes an online community with entries of commentary, descriptions of events, and other materials such as graphics and videos. Readers interact with the published materials in blogs and entries that are reversed chronologically.

Arslan and Sahin-Kiz1l (2010) conducted a quasi-experimental study to explore the effect of blog-centered writing instruction on students' writing performance. Participants were 50 third grade EFL students at a Turkish university. They were divided into control and experimental groups. The control group $(n=23)$ received in-class process-oriented writing instruction and the experimental group $(n=27)$ integrated blogs into their writing processes. Based on the analyses of students' written work, the findings revealed that blogintegrated writing instruction significantly improved students' writing.

Sidek and Yunus (2012) tried to examine students' experiences in using blogs as learning journals. Participants were 60 junior students studying a Public Speaking course at a university in Malaysia. Qualitative data were collected by interviewing the participants and observing their journal entries. Findings revealed that participants enjoyed interacting with others in blogs. They felt self confident when reflecting on their journal entries.

The study of Ozkan (2015) aimed to highlight students' views on the effect of using blogs in an English language course. Participants were 44 non-English major first-grade undergraduate students at a university in Turkey. A questionnaire and an interview were administered to the participants. Their responses revealed the positive effect of using blogs on language learning since blogs encouraged them to participate and interact 
with their colleagues and instructors which positively affected their language learning.

\section{Twitter}

Crane (2012) defines Twitter as an online service, introduced in 2006, that enables users to share short messages with their followers. A tweet is a text-based post of 140 characters or less. It enables students to practice the skill of summarizing. Armfield et al. (2015) add that Twitter requires short and to- the- point messages. Links, videos, and photographs are easily attached to tweets. Users can comment on and share each other's tweets. Hamidon et al. (2013) conclude that Twitter offers instant feedback, easy access, hashtag, and retweet. The limited number of characters in each tweet encourages students to use words creatively.

Bicen and Cavus (2012) highlight the educational use of Twitter. The technical structure and characteristics of Twitter encourage teachers to use it in education. Zaina et al. (2014) assert that Twitter is a useful resource to support learning outside the classroom. Students can communicate, collaborate, and share ideas using short messages. Richardson (2010) maintains that Twitter is a powerful tool for teachers to share content. Students can communicate with their teachers and get instant feedback. Finally, teachers can encourage students to use Twitter on their mobile phones.

Research done by Lomicka and Lord (2012) proved that Twitter can help language learners form a collaborative community to learn, share, and reflect on the learning content. The participants were 30 students enrolled in an intermediate French course in a south eastern university in the United States and 12 native French speakers enrolled in an intermediate-high English conversation course in France. Participants tweeted weekly with each other and with peers in the other country using English and French languages. Analysis of participants' responses on an attitude questionnaire revealed that using Twitter enabled students in both countries to form a learning community that offered them opportunities for interactive language practice outside classrooms.

Ahmed (2015) examined the effect of using twitter on EFL writing. Participants were 60 female English language students from a College of Arts and Sciences in Saudi Arabia. The college offered eight levels of English Language to the students. Participants were enrolled in level four 
and divided into an experimental group $(n=30)$ and a control one $(n=30)$. The study followed a pre-posttest experimental-control group design. The experimental group studied the writing course using Twitter in the first semester of 2014. The findings revealed that the experimental group outperformed the control one in the post test.

\section{Skype}

Crane (2012) defines Skype as a software application that allows users to make voice calls and videoconferences over the Internet. Since 2003, Skype has allowed educators to open their classrooms to the world. It offers various learning opportunities, for instance classes can interview experts or go on virtual field trips. Skype develops students' communication skills: They read books, write questions for the call, speak to the guest(s), and listen to new information. In addition, Skype encourages students to appreciate differences in appearance, culture, traditions, language, dialects, and countries.

Taillefer and Munoz-Luna (2014) aimed to analyze L2 usage in the oral interaction between university students from Hong Kong and Spain. Participants were 20 Spanish and Chinese students of English enrolled in a Skype-mate Language Project. The study followed a mixed methodology. Quantitative data were gathered via observation of students' conversations, in addition to qualitative data obtained from students' responses to an online questionnaire after each conversation. The findings revealed that Skype enhanced oral communication skills and cultural awareness of the participants.

Yen , Hou, and Chang (2015) aimed to examine the effect of roleplaying strategy on developing university students' writing and speaking skills in an English conversation course studied for an academic semester. The course was administered via Facebook asynchronously and via Skype synchronously. Participants were 42 students from a Business College in Taiwan. The findings revealed the development of the participants' speaking and writing skills.

\section{Edmodo}

Crane (2012) and Gan, Menkhoff, and Smith (2015) define Edmodo as a collaborative social learning platform designed for teachers and students to close the gap between them. It integrates students' lives inside and outside schools. It was introduced in 2008 by Nic Borg, Crystal 
Hutter, and Jeff O'Hara. Edmodo ensures safety and privacy in sharing content and accessing homework, grades, and school notices as each student has an access code. It enables both teachers and students to manage events, assignments, study groups, and any activities. Links, videos, documents, and other resources can easily appear on the Edmodo pages.

The study of Krutka, Bergman, Flores, Mason, and Jack (2014) investigated the possibilities and challenges of using Edmodo as a reflective tool. Participants were 77 junior pre-service teachers from different specializations at a Midwestern university, USA. They were enrolled in an on-campus literacy class with an online reflection log. Participants were asked to post at least three posts and comments per week. Findings indicated that Edmodo was user-friendly and fostered interactions among students and their instructors. Instructors asserted that collaborative reflection led to professional development for pre-service teachers.

Balasubramaniana, Jaykumar, and Fukey (2014) tried to examine the effect of using Edmodo on students' learning engagement. Participants were 249 diploma and master students at a private university in Malaysia. They were purposefully selected during the Fall semester of 2013. An online questionnaire was designed using the Resources, Activity, Support and Evaluation (RASE) model. The results of the study showed that Edmodo was a user-friendly social learning platform that increased students' learning engagement.

Thibaut (2015) investigated the use of Edmodo to develop literacy for 30 sixth grade students at a school in Australia. The researcher collected participants' daily entry logs on Edmodo for four months. Data analysis of a survey, students' logs, and interviews revealed that that the use of Edmodo allowed students to engage in digital literacy practices, selflearning activities, and peer instruction.

The study of Al-Kathiri (2015) tried to highlight the possibilities and challenges of using Edmodo in EFL classrooms in Saudi Arabia. Participants were 42 female second grade students at a public secondary school. They participated daily in an Edmodo classroom for six weeks. An attitude questionnaire was administered to the students by the end of the study. The findings revealed that students' perceptions towards using Edmodo in EFL were highly positive. 


\section{YouTube}

Harris (2008) sates that YouTube is a video sharing network launched in February 2005. It is a host service that allows users to upload video clips to be available to other users. Crane (2012) adds that users can upload, share, and view videos. The logo of Youtube is broadcast yourself to encourage participants to share their videos.

Elsayed (2014) determined the effectiveness of YouTube videos on developing speaking skills of the second year preparatory school students. Two EFL female classrooms were selected from a public school in Mansoura, an Egyptian city, and were assigned to a control and an experimental group. The researcher administered 16 online Youtube sessions to the experimental group while the control one received regular instruction. The findings revealed that the use of Youtube video was effective in developing EFL students' speaking skills.

Mallhe (2014) explored the effect of using YouTube videos as supplementary learning materials on developing students' EFL listening comprehension. Participants were 72 students from level 2 of the English language program at a public university in Saudi Arabia. Findings of the statistical analysis of the post administration of the listening comprehension test and attitude survey revealed the effectiveness of YouTube video clips in developing participants' listening comprehension skills.

\section{Conclusion}

This article sheds light on the importance of social media applications appeared in the Web 2.0 age. Availability, interactivity, and simplicity are often attributed to social media, that is why they should be integrated in the learning situations. Integrating social media in EFL encourages students to interact with native language speakers, acquire new information, and explore different cultures. Social media applications enable teachers to offer personalized learning instruction to students anywhere and anytime. Students' motivation, participation, and attitudes towards learning are affected positively when using social media in learning.

Social media provide students with opportunities to practice language skills in authentic situations. Students create collaborative learning 
communities where they enjoy the learning process. Based on the previously mentioned research, Facebook is used for developing students' reading, writing, and listening skills. Also, Skype is used for developing students' speaking skills. Twitter develops students' writing and speaking skills. Blogs are used to develop students' writing skills in a process based teaching. Youtube is used to develop students' listening skills. Edmodo is mainly developed for educational purposes.

The Ministry of Education in Egypt tends to encourage students to benefit from different online learning resources. Logging into its website, students can access text books, model exams, and different interactive lessons. Also, there is an online learning unit in The Ministry of Education which means the gradual transformation into online learning. Most schools in Egypt have resource learning rooms with internet access and some of them have Wifi in the classrooms.

Professional Academy for Teachers in Egypt has to offer training on online learning. Teachers need to master the skills needed to offer ubiquitous learning. They should have positive attitudes towards integrating social media in learning. The school administration should allow Internet access in classrooms for the inclusion of online activities in the learning process. EFL teachers should select interesting topics, review online resources, and allow active discussion in the classroom.

Further, schools should offer symposiums to parents to highlight the potential of using social media in EFL. Parents can monitor their children's progress by sending them online reports. Parents can send feedback on their children's attitudes towards integrating social media in learning. They can collaborate with teachers to offer online activities that satisfy students' needs.

Regulations in Egypt force students to attend schools, so using social media can be integrated in a blended learning framework. Blended learning means the combination of face-to-face instruction and online learning. EFL instructors should conduct surveys to identify the social media mostly used by their students to tailor different learning experiences. To sum up, teachers are responsible for offering instruction that copes with recent trends. They have to encourage their students to be autonomous learners. Using social media in EFL not only develops students' language skills but also offers them meaningful learning experiences. 


\section{References}

Ahmed, M.(2015).The Effect of Twitter on Developing Writing Skill in English as a Foreign Language. Arab World English Journal (AWEJ, $2,134-149$.

Anderson, T. (Ed.). (2008). The theory and practice of online learning ( $2^{\text {nd }}$ ed.). Canada: Athabasca University Press.

Armfield, S., Armfield , D. , \& Blocher, M.(2015). Online collaboration and social networking. In R. Papa (Ed.), Media rich instruction: Connecting curriculum to all learners (pp. 189-202). New York: Springer Science+Business Media.

Arslan, R.\& Sahin-K1z1l, A. (2010). How can the use of blog software facilitate the writing process of English language learners?

Computer Assisted Language Learning , 23(10), 183-197.

Balasubramanian, K., Jaykumar, V., \&Fukey, L.(2014). Student preference towards the use of Edmodo as a learning platform to create responsible learning environment. Procedia - Social and Behavioral Sciences, $144,416-422$.

Baniabdelrahman, A.(2013).The effect of using online tools on ninth grade Jordanian students' vocabulary learning. Arab world English journal, 4(1), 189-202.

Baöz, T.(2016). Pre-service EFL teachers' attitudes towards language learning through social media. Procedia - Social and Behavioral Sciences $232,430-438$.

Bicen, H. \& Cavus, N.(2012). Twitter usage habits of undergraduate students. Procedia - Social and Behavioral Sciences, 46 ,335 - 339.

Bonsignore, E., Hansen, D. Galyardt, A., Aleahmad,T. , \& Hargadon, S. (2011). The power of social networking for professional development. In T. Gray and H. Silver-Pacuilla (Eds.), Breakthrough teaching and learning: How educational and assistive technologies are driving innovation (pp.25-52). New York: Springer Science+Business Media.

Caplan, D.(2008). The development of online courses. In A.Terry (Ed.), The theory and practice of online learning ( $2^{\text {nd }}$ ed.), (pp.245-265). 
Canada: Athabasca University Press.

Crane, B. (2012).Using Web 2.0 and social networking tools in the K-12 classroom. Chicago: American Library Association.

Danciua, E.\& Grosseck,G.(2011). Social aspects of web 2.0 technologies: teaching or teachers' challenges? Procedia Social and Behavioral Sciences $15,3768-3773$.

EL-Desouky, G.(2015). Utilizing mobile assisted language learning to develop EFL listening skills and learner autonomy (Unpublished MA. Thesis). Egypt : Mansoura University.

Dede, C.(2011). Reshaping the role of technology in education. In G. Tracy \& S.Heidi, (Eds.) Breakthrough teaching and learning. How educational and assistive technologies are driving innovation (pp.1-3).

New York: Springer Science+Business Media.

Fahy, P.(2008). Characteristics of interactive online learning media. In T. Anderson (Ed.). The theory and practice of online learning ( $\left.2^{\text {nd }} \mathrm{ed}.\right)$, (pp. 167-200). Canada: Athabasca University Press.

Feldmann, B.(2014).Two decades of e-learning in distance teaching From web 1.0 to web 2.0 at the University of Hagen. In L. Uden, J.

Fox-Turnbull, W.(2015).Conversations to support learning in Technology Education. In J. Williams. , A. Jones, \& C. Buntting. (Eds.), The future of technology education: Contemporary issues in technology education (pp.99-119). Singapore: Springer Science+ Business Media.

Gan, B., Menkhoff, T., \& Smith, R.(2015). Enhancing students' learning process through interactive digital media: New opportunities for collaborative learning. Computers in Human Behavior 51 , 652-663.

Green ,L., Hechter, R., Tysinger, D., \& Chassereau, K.(2014). Mobile app selection for 5th through 12th grade science: The development of the MASS rubric. Computers \& Education $75,65-71$.

Gros, B. Kinshuk, \& Maina, M. (2016). The future of ubiquitous learning. Berlin: Springer- Verlag. 
Hamidon, S., Alias, N., Siraj, S., Kokila, K., Mohammed, M., \& Thanabalana, T. (2013). Potential of Twitter in post-reading activities among community college students in Malaysia. Procedia - Social and Behavioral Sciences 103, $725-734$.

Harris, D.(2008).Web 2.0 evolution into the intelligent Web 3.0. Australia: Emereo Pty Ltd.

Hutchison, M., Tin ,T., \& Cao , Y.(2008).“In-Your-Pocket” and "On-theFly:" Meeting the needs of today's new generation of online learners with mobile learning technology. In T. Anderson (Ed.), The theory and practice of online learning ( $2^{\text {nd }} \mathrm{Ed}$.), ( pp. 201-220). Canada: Athabasca University Press.

Hwang, W., Chen, H. Huang, R., and Chen, C.(2014) Improving English as a foreign language writing in elementary schools using mobile devices in familiar situational contexts. Computer Assisted Language Learning , 27 (95), 359-378.

Internet and social media use among Egyptians.(2016). Retrieved from http://www.dailynewsegypt.com/2016/01/04/report-details-internetand-social-media-use-among-egyptians on March $11^{\text {th }}, 2016$.

Al-Kathiri, F.(2015).Beyond the classroom walls: Edmodo in Saudi secondary school EFL instruction: Attitudes and challenges. English Language Teaching, 8( 1), 189-204.

Krutka,D., Bergman,D., Flores,R., Mason, K. ,\& Jack, A. (2014). Microblogging about teaching: Nurturing participatory cultures through collaborative online reflection with pre-service teachers. Teaching and Teacher Education 40, 83-93.

Lomicka, L. \& Lord, G. (2012). A tale of tweets: Analysing microblogging among language learners. System, 40, 48-63.

Mallhe, A. (2014). Effects of YouTube listening/viewing mash-ups via blackboard on Saudi EFL college learners' listening comprehension. Mansoura Faculty of Education Magazine, 87 (1), 81-102.

Manca, S., \& Ranieri, M.( 2016). Facebook and the others: Potentials and obstacles of Social Media for teaching in higher education.

Computers \& Education 95 , 216-230. 
Mao, J.(2014). Social media for learning: A mixed methods study on high school students' technology affordances and perspectives. Computers in Human Behavior, 33 ,213-223.

McClanahan, B. \& Stojke, A.(March 2015). Mobile devices for struggling readers in the classroom. Practice and Evaluation 3, 143-164.

Mioduser, D.(2015).The Pedagogical ecology of technology education: An Agenda for Future Research and Development. In J. Williams , A. Jones, \& C. Buntting (Eds.), The future of technology education: Contemporary issues in technology education (pp. 77- 97).

Singapore: Springer Science+Business Media.

Moisey, S. \& Hughes, J.(2008). Supporting the online learner. In T. Anderson (Ed.), The theory and practice of online learning $\left(2^{\text {nd }} \mathrm{ed}.\right)$, (pp. 419-439). Canada: Athabasca University Press.

Mozaheb, M., Seifoori, Z., \& Beigi, A.(2013). Effective Iranian EFL writing teachers (a technology-based framework). Procedia - Social and Behavioral Sciences 70 , $18-27$.

Nisr, N.(2014). The perceptions of social media in Libya (Unpublished $\mathrm{PhD}$. Dissertation). Washington State University. Retrieved from:www.sciencedirect.com on January $15^{\text {th }}, 2016$.

Oberg, A., \& Daniels , P.(2013). Analysis of the effect a studentcentred mobile learning instructional method has on language acquisition. Computer Assisted Language Learning , 26(2), 177-196

Ozkan, M. (2015).Wikis and Blogs in foreign language learning from the perspectives of learners. Procedia - Social and Behavioral Sciences, $192,672-678$.

Papa, R. (Ed.).(2015).Media rich instruction: Connecting curriculum to all learners. New York: Springer Science+Business Media.

Pletka, B.(Ed.)(2007). Educating the net generation. How to engage students in the $21^{\text {st }}$ Century. United States :Santa Monica Press LLC. 
Riedl, J. (2008)Altruism, selfishness, and destructiveness on the social Web. In W. Nejdl, J. Kay, P. Pu, \&E. Herder (Eds.) Adaptive hypermedia and adaptive Web-based systems. Germany : SpringerVerlag Berlin.

Richardson, W. (2010). Blogs, Wikis, Podcasts, and other powerful Web tools for classrooms. California: Corwin

Rosen, Anita. (2009).E-learning 2.0 proven practices and emerging technologies to achieve results. New York: American Management Association

Santos-Trigo , M. \& Reyes-Martínez ,I.(2014). The Coordinated use of digital technologies in learning environments. In L. Uden, J. Sinclair, Y. Tao, \& D. Liberona (Eds.) Learning technology for education in Cloud MOOC and big data (pp. 61-71). Switzerland: Springer International Publishing.

El-Sayed, Z.(2014). Using Youtube video-based instruction to develop EFL preparatory stage pupils' speaking skills ( Unpublished MA. Thesis). Egypt: Mansoura University.

El-Sawy, H.(2015). The impact of facebook as a free writing tool on developing EFL writing skills. Banha Faculty of Education Magazine, 26 (104), 1-28.

Schroeder, R.(2011). Being there together: Social interaction in shared virtual environments. England: Oxford University Press.

Shieh, R.(2012). The impact of technology-enabled active learning (TEAL) implementation on student learning and teachers' teaching in a high school context. Computers \& Education 59 ,206-214.

Sidek, E. \& Yunus, M.(2012). Students' experiences on using Blog as learning journals. Procedia - Social and Behavioral Sciences 67 , $135-143$

Sinclair, Y. Tao, \& D. Liberona (Eds.) Learning technology for education in Cloud MOOC and big data (pp. 163-172).Switzerland: Springer International Publishing.

Taillefer,L. and Munoz-Luna, R.(2014). Developing oral skills through 


\section{Hager Gamal Ahmed Labib al-Tonsi}

Skype: A language project analysis. Procedia - Social and Behavioral Sciences 141, $260-264$.

Thibaut, P.(2015). Social network sites with learning purposes: Exploring new spaces for literacy and learning in the primary classroom. Australian Journal of Language and Literacy, 38(2), 83-94

Veletsianos, G.(2010). A definition of emerging technologies for education. In G. Veletsianos (Ed.), Emerging technologies in distance education. (pp.3-22). Asthabasca: Asthabasca University Press.

Vision of e-marketing in Egypt. (2015).Retrieved from http://www.fedcoc.org.eg/c2964 on April 10th,2016.

Yen , Y., Hou, H., \& Chang, K.(2015). Applying role-playing strategy to enhance learners' writing and speaking skills in EFL courses using Facebook and Skype as learning tools: a case study in Taiwan. Computer Assisted Language Learning 28 (5), 383-406.

Yusof,J. Manan,N. and Alias,A.(2011). Guided peer feedback on academic writing tasks using Facebook notes: An exploratory study. Procedia - Social and Behavioral Sciences 67, 216- 228

Zaina, L., Ameida,T. and Torres,G.(2014). Can the online social networks Be used as a learning tool? A case study in Twitter. In L.Uden, J. Sinclair ,Y. Tao,\& D. Liberona (Eds.), Learning technology for education in Cloud MOOC and big data (pp. 114-123)Switzerland: Springer International Publishing.

Zhang, Y.(2009). Collaborative learning in a Web-based environment: A comparison study. In C. Mourlas, N. Tsianos, \& P. Germanakos (Eds.), Cognitive and emotional processes in Web-based education: Integrating human factors and personalization (pp. 344-356) Hershey: IGI Global. 
